\title{
Modeling of a concentrating photovoltaic module
}

\author{
Intissar. BENRHOUMA \\ Research Unit: Environment, Catalysis and Process Analysis \\ National Engineering School of Gabes \\ Gabes, Tunisia \\ intissar19913@yahoo.fr \\ Marta. VICTORIA \\ Solar Energy Institute \\ Polytechnic University of Madrid \\ Madrid, Spain \\ Ignacio. ANTON HERNANDEZ \\ Solar Energy Institute \\ Polytechnic University of Madrid \\ Madrid, Spain \\ Bechir. CHAOUACHI \\ Research Unit: Environment, Catalysis and Process Analysis \\ National Engineering School of Gabes \\ Gabes, Tunisia
}

\begin{abstract}
The photovoltaic systems are characterized by low efficiency. To improve their efficiency we need to use concentrating photovoltaic systems. These CPV systems allowed the enhancing of the power which received by the cell. This high power can raise the potential of the electrons causing the heating of the cell, which minimizes the photovoltaic efficiency of the module.

This work has the role to model a concentrating photovoltaic module without and with cooling system. We have established a theoretical model based on energy balances. Using MATLAB, the obtained results, allow us to compare between CPV module with and without cooling system and to know the importance of adding the cooling system. Those results indicated the improvement of CPV systems' efficiency.
\end{abstract}

Keywords-Concentration; Cooling; Performance improvement; Photovoltaic; Solar energy

\section{INTRODUCTION}

The progression of new sources of energy is continuously improved due to the critical situation of industrial chemical fuels such as oil, gas and others. So, renewable energy sources have become most important contributors of the total energy consumed in the world. In fact, the request of solar energy has risen from $20 \%$ to $25 \%$ since the last 20 years.

Among the various photovoltaic technologies, the latest at present is the photovoltaic concentrate, also called concentration photovoltaic. High efficiencies are the main advantages of concentrating photovoltaic systems; such systems use semiconductors less expensive than conventional PV to obtain a specified electrical output. Through concentrating the sun's rays, the solar radiation's intensity can be raised by partial or several times of its standard output. This allows a reduction in the cell surface required for the production of an energy quantity. The goal is to decrease the cost of the produced electricity by the substitution of expensive PV with cheaper optical equipment. This approach offers the possibility of using high-performance PV cells. [1]

CPV systems classified according to the concentration factor in three categories. In the case of low concentration, the concentration factor is less than 10 suns. When the concentration is between $10-100$ suns, it is the case of medium concentration, whereas it is between 100-1000 for a high concentration.

A. Zahedi [2] explains that thermal management is an important issue for the photovoltaic system, regardless of whether conventional or concentrated. He states that PV cells convert a small part of the solar radiation into electrical energy, the rest of electrons are dissipated in these cells in the form of heat, this heat influenced negatively on the efficiency of the PV module and it results an increase in the temperature which leads to decreased the cell efficiency and the destruction of its crystal structure. To avoid long-term damage to the cell based on Silicon, the temperature must not exceed $60^{\circ} \mathrm{C}$.

According to Pérez-Higueras et al. [3], the main effect of 
the cell temperature's raising is the reduction of the open circuit cell voltage which affects on the maximum electrical power. For that, the efficiency of the solar cell was decreased. For this purpose it is important to check the operating temperature of the CPV module, which is done by a cooling system.

Royne et al. have proposed various cooling technics for the cooling of photovoltaic cells in CPV systems. These technics aim to achieving a low and uniform cell temperature using simple drawings, including passive cooling or active cooling. The technics of passive cooling are used with linear concentrators such as the system where the concentration ratio is low, around 20 suns. In addition, the heat is dissipated by natural cooling, natural convection. While in the case of high concentration ratio and high temperature, the heat is discharged to the back of the solar cell by a fluid cooling system, generally water. However, for heigh concentration levels, the air cooling is insufficient. So there is a need for a forced cooling system that uses water, for example. [4]

\section{CoOling System for CONCENTRATING Photovoltaid SYSYTEM}

In photovoltaic systems, the solar radiations are partially converted into electrical energy by its striking on the solar cell. The rest of energy is converted into thermal energy. In the concentrating photovoltaic systems, due to the very large quantity of the light incident on the cells, the CPV module attains very high temperatures [5]. Moreover, the resistive losses on the cell canal contribute to the increase in cell temperature [6]. Indeed, an increase in the cell temperature reduces the band width which leading to a decrease in the open-circuit cell voltage (Voc) and the short-term or even leading to an irreversible damage on long-term effectiveness. Thus, the cell must be kept at low temperatures; the heat produced must be extracted from the cell. The CPV systems can include a cooling mechanism which its design considerations should follow some important criteria: $[4,5]$

- Low temperatures: solar cells have a maximum operating temperature; a value above this operating temperature can show a long-term abasement of the operation of devices. Furthermore, the efficiency of CPV module decreases when the cell temperature increases, so the solar cells must work at low temperatures.

- Temperature uniformity: at this stage, two situations must be considered: a) The solar cell efficiency decreases with the non-uniformity of the cell temperature; And b) in a CPV module, the solar cells are usually attached in series. Therefore, the open circuit Voc is limited by its lowest value which means that at high temperature all the cells in the chain must be work under the same temperature in order to attain a maximum value of efficiency.

- Minimum needs: The cooling system must have a minimum of servicing and a minimum of energy consumption in order to maintain the CPV system total cost as low as possible.
Cooling systems can be distributed into passive and active. In on hand, passive cooling relies on solutions such as solution integrated heat sinks or can simply the back surface of the CPV module interchange heat with ambient air. In the other hand, for the active cooling, generally a fluid is used to absorb heat from the cells. The passive cooling option is generally preferred because it is simpler, less expensive, maintenance free and avoids using water.

\section{THERMAL MODEL AND ASSUMPTIONS}

For the modeling we work with a model which has four main layers; a layer of the solar cell which based on Silicon, the copper layer, the alumina filled epoxy (insulation layer) and the Aluminum layer; the figure 1 showing the equivalent thermal circuit,

As a first step we work within cooling system, the CPV model delivered to the natural convection, and for the second step we introduce the same CPV model but with a cooling system. The information of irradiance and air temperature are given by the solar energy institute where localized in Madrid.

We will determine the cell temperature at the Concentrator Standard Operating Conditions CSOC (CSOC, DNI=900 $\mathrm{W} / \mathrm{m} 2$, ambient temperature $=20{ }^{\circ} \mathrm{C}$ and wind speed $=2 \mathrm{~m} / \mathrm{s}$ ) as defined in (IEC committee 2013) [7] in the two case then by the value of cell temperature we can found the other temperature of each layers.

\section{A. Method}

In this work, a single solar cell is explored using Matlab software. In fact, on one hand the CPV module exposed to the natural convection in the case of a CPV module within a cooling system. On the other hand, the solar cell was placed on a dispositive which contacted with water cooling channel to study the thermal model of the active cooling's effects. The heat conduction and convection equations have been solved simultaneously.

The following figure is the equivalent thermal circuit for the concentrating photovoltaic module:

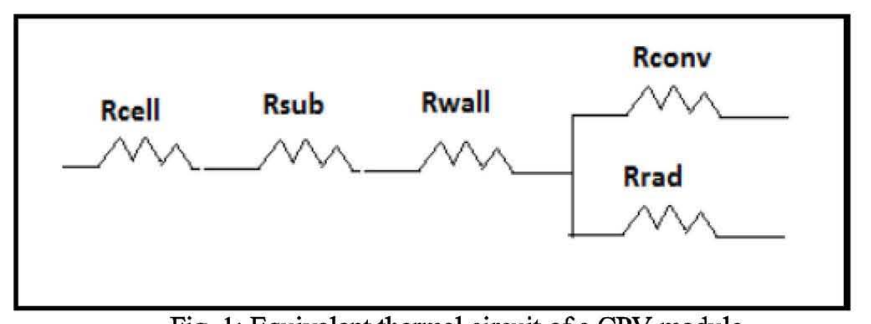

Fig. 1: Equivalent thermal circuit of a CPV module

\section{B. Balances Energy}

When the solar cell begins to receive solar power, electric power is generated as well as heat to be dissipated. At first, when current is starting to flow, the heat transfer rate varies according with time; it is called the dynamic mode or transient state. Then, the heat transfer rate becomes constant and does not vary at all; this is the steady state. So two different states are possible, but in general, cells work at the steady state, because the dynamic state is too short in 
comparison with the working time at steady state. However, in a day of intermitent clouds the cells may work at the transient state often, so the dynamic behaviour is also considered. But first the thermal study of the concentrator is presented for the steady state $(\partial . / \partial \mathrm{t}=0)$

According to the heat transfer mechanisms, the conduction and then the convection and radiation. Modeling assumes uniform cell temperature or uniform irradiance on the cell.

We are doing the balance energy on each material; the solar cell, the substrate and the wall. We use the formula which the inlet energy equal to the outlet energy.

$$
Q_{\text {in }}-Q_{\text {out }}=0
$$

In order to be able to model the CPV module, many assumptions and boundary conditions have been considered:

- The area of the wall equals twice the area of the lens.

- The convective and the radiation coefficient are very small between the lens and the solar cell, we supposed that are negligible.

- Solar cell:

$$
\text { B. } \eta_{\text {opt }} \cdot\left(1-\eta_{p v}\right)-\frac{1}{R_{\text {cell }}} \cdot\left(T_{c e l}-T_{\text {sub }}\right)=0
$$

Where $\mathrm{R}_{\text {cell }}$ is the solar cell thermal resistance and it equal the division of the thermal conductivity by the thickness. $T_{\text {cell }}$ and $T_{\text {sub }}$ are the temperatures of the solar cell and the substrate.

- Substrate:

$$
\frac{1}{R_{\text {cell }}} \cdot\left(T_{\text {cel }}-T_{\text {sub }}\right)-\frac{1}{R_{\text {sub }}} \cdot\left(T_{\text {sub }}-T_{\text {wall }}\right)=0
$$

Where $R_{\text {sub }}$ is the substrate thermal resistance and $T_{\text {wall }}$ is the temperature of wall.

- Wall:

$$
\begin{gathered}
\frac{1}{R_{\text {sub }}} \cdot A_{\text {wall }} \cdot\left(T_{\text {sub }}-T_{\text {wall }}\right)-h_{\text {conv }} \cdot A_{\text {wall }} \cdot\left(T_{\text {wall }}-T_{a}\right) \\
-\varepsilon \cdot \sigma \cdot A_{\text {wall }} \cdot\left(T_{\text {wall }}^{4}-T_{a}^{4}\right)=0
\end{gathered}
$$

Where $h_{\text {conv }}$ is the natural convective coefficient, $A_{\text {wall }}$ is the wall area, $T_{a}$ is the ambient temperature, $\sigma$ is StefanBoltzmann coefficient, $\varepsilon$ is the emissivity of the wall.

According to the CSOC, the $h_{\text {conv }}$ equal to $15 \mathrm{~W} / \mathrm{m}^{2} \mathrm{~K}$ $(\mathrm{V}=2 \mathrm{~m} / \mathrm{s})$.

For the adding of the cooling system, we use as cooling fluid the water, with a velocity equal $20 \mathrm{~cm} / \mathrm{s}$. The difference between the two cases is that the first, the aluminum layer is in contact with the environment by natural convection. But in the second case, the aluminum layer was contacted to the cooling fluid which is at the ambient temperature.

\section{Performance of the CPV modeling}

- Efficiency of the CPV module

$$
\eta_{p v}=\frac{Q_{\text {elect }}}{B \cdot \eta_{\text {opt }}}
$$

$\eta_{\mathrm{pv}}$ is the efficiency of the concentrating photovoltaic module, Qelect is the electrical power, B is the irradiance absorbed by the lens and $\eta_{\text {opt }}$ is the optical efficiency which equal to $85 \%$.

\section{Data tables}

\begin{tabular}{|l|c|c|c|c|c|}
\hline & $\begin{array}{c}\text { Thickn } \\
\text { ess e } \\
(\mathbf{m m})\end{array}$ & $\begin{array}{c}\text { Thermal } \\
\text { conductiv } \\
\text { ity } \\
\mathbf{k}(\mathbf{W} / \mathbf{K m})\end{array}$ & $\begin{array}{c}\text { Absorptio } \\
\mathbf{n} \\
\text { coefficient } \\
\boldsymbol{\alpha}\end{array}$ & $\begin{array}{c}\text { Transmitt } \\
\text { ance } \\
\text { coefficient } \\
\boldsymbol{\tau}\end{array}$ & $\begin{array}{c}\text { Emissivity } \\
\text { coefficient } \\
\boldsymbol{\varepsilon}\end{array}$ \\
\hline $\begin{array}{l}\text { Fresnel } \\
\text { lens }\end{array}$ & 3 & - & 0,05 & 0,8 & 0,855 \\
\hline $\begin{array}{l}\text { Silicon } \\
\text { solar cell }\end{array}$ & 0,3 & 148 & 0,85 & - & - \\
\hline Solder & 0,2 & 50 & - & - & - \\
\hline $\begin{array}{l}\text { Substrat in } \\
\text { Copper }\end{array}$ & 0,3 & 401 & - & - & - \\
\hline $\begin{array}{l}\text { Alumina } \\
\text { filled epoxy }\end{array}$ & 0,075 & 1,3 & - & - & - \\
\hline Solder & 0,2 & 50 & - & - & - \\
\hline $\begin{array}{l}\text { Wall in } \\
\text { aluminium }\end{array}$ & 2 & 201 & - & - & 0,77 \\
\hline
\end{tabular}

TABLE 1: PROPRIETIES OF THE MATERAILS CONSIDERED IN MATLAB SIMULATION

\section{RESULTS}

All the results were obtained in the Solar Energy Institute in Madrid at 14/11/2016.

\section{A. Flat Plate within cooling system (natural convection between the wall and the ambient air)}

For the CSOC conditions, with an iterative calculation, we found that $\mathrm{T}_{\text {cell }}=65.92^{\circ} \mathrm{C}, \mathrm{T}_{\text {sub }}=43.37^{\circ} \mathrm{C}, \mathrm{T}_{\text {wall }}=41.74^{\circ} \mathrm{C}$, module efficiency $=0.187$.

We assume that the area available of the wall equals twice of the area of the optical concentrator used, which can simply be calculated as the product of the cell area and the geometrical concentration ratio. The layer plate is supposed to be in aluminum with a thermal conductivity of $201 \mathrm{~W} / \mathrm{mK}$ and a thickness of $2 \mathrm{~mm}$, while all the heat transfer coefficients from the exposed surfaced are calculated supposing natural convection from a vertical plate. 


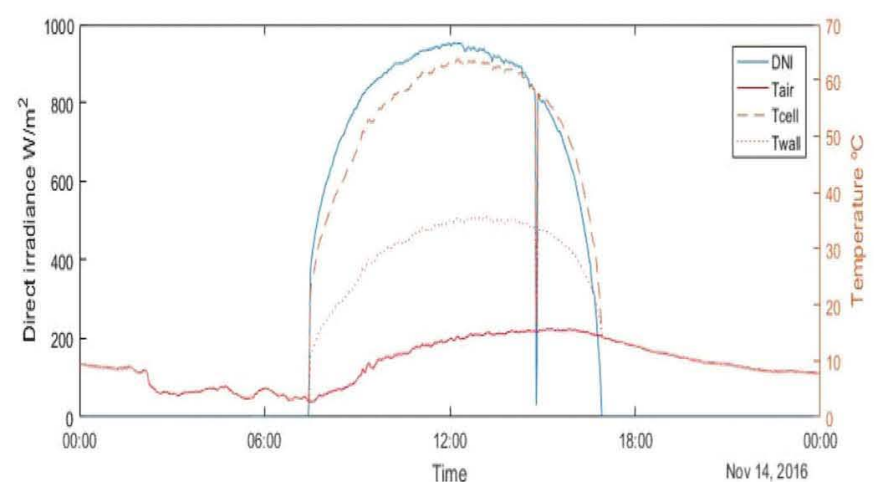

Fig. 2: Cell and Wall temperatures as a function of ambient temperature and $D N I$

Figure 2 presents the variation of the irradiance during the day of $14 / 11 / 2016$, in Madrid. This variation has a maximum value at the mid morning. We observed that the solar cell can rise a temperature of $65^{\circ} \mathrm{C}$ and the wall temperature can rise a value of $35^{\circ} \mathrm{C}$. Those two temperatures are related to the variation of the direct irradiance.

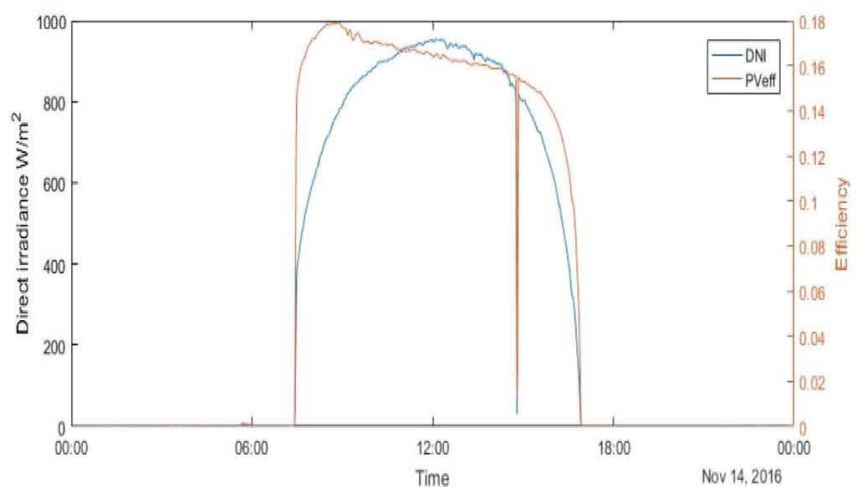

Fig. 3: Photovoltaic efficiency for the CPV module as a function of $D N I$

Figure 3 indicate the variation of the photovoltaic efficiency as a function of DNI. $\eta_{\mathrm{pv}}$ can rise a value equal to $18 \%$, which is a small value, and it is related to the evolution of the DNI.

\section{B. Flat Plate with cooling system (water cooling)}

In this case the fluid cooling is the water, the flowing table presents its characteristics that we use in the modeling.

\begin{tabular}{|c|c|c|c|}
\hline $\begin{array}{c}\text { Cooling } \\
\text { fluid }\end{array}$ & $\begin{array}{c}\text { Density } \boldsymbol{\rho} \\
\mathbf{K g} / \mathbf{m}^{3}\end{array}$ & $\begin{array}{c}\text { Velocity v } \\
\mathbf{c m} / \mathbf{s}\end{array}$ & $\begin{array}{c}\text { Specific heat Cp } \\
\mathbf{J} / \mathbf{K g ~ K ~ K}\end{array}$ \\
\hline Water & 1000 & 20 & 4182 \\
\hline
\end{tabular}

\section{TABLE 2: WATER CARACTERISTICS}

We assume that the water enter in a temperature equal to the ambient temperature, with the area equal, $100 \times 2 \mathrm{~cm}^{2}$.

We have to calculate at first all the temperature and the photovoltaic efficiency in the CSOC conditions. So we found that $\mathrm{T}_{\text {cell }}=43.73^{\circ} \mathrm{C}, \mathrm{T}_{\text {sub }}=26.36^{\circ} \mathrm{C}, \mathrm{Q}_{\mathrm{e}}=1.63 \mathrm{~W} / \mathrm{cm}^{2}$ and $\eta_{\mathrm{pv}}=$ 0.2151 . We use the data of the $14 / 11 / 2016$ and we simulate, with Matlab, all the temperatures and the photovoltaic efficiency $\eta_{\mathrm{pv}}$.

We obtain the following figure:

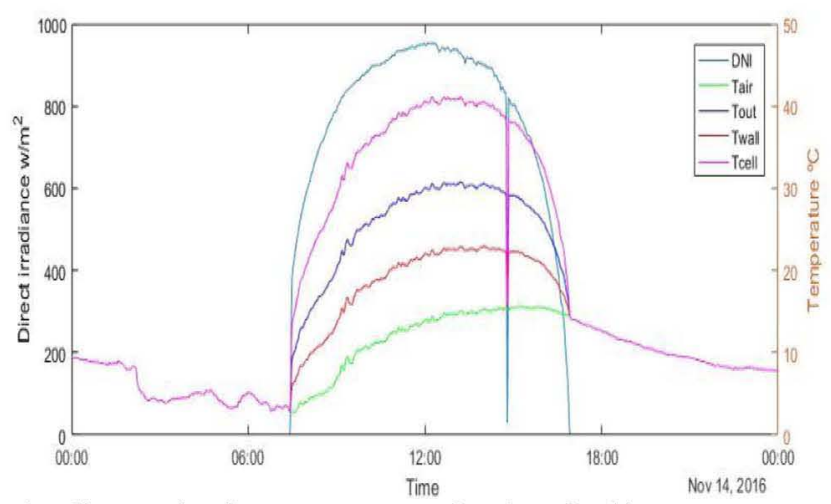

Fig. 4: cell, out and wall temperatures as a function of ambient temperature and $D N I$

Figure 4 evinces all the temperatures as a function of DNI. The cell temperature can rise a value equal to $46^{\circ} \mathrm{C}$ moreover the wall temperature equal to $24^{\circ} \mathrm{C}$. The out temperature of the water cooling can raise a value equal to $30^{\circ} \mathrm{C}$. We interpret that the out temperature of water is increasing but in other side the cell and the wall temperatures are decreasing. So we can introduce that the adding of a cooling system have an influence on the cell temperature. Also it has an influence on the photovoltaic efficiency that we can observe it in the figure 5 . As showing in the figure $5, \eta_{\mathrm{pv}}$ can rise a value equal to $22 \%$.

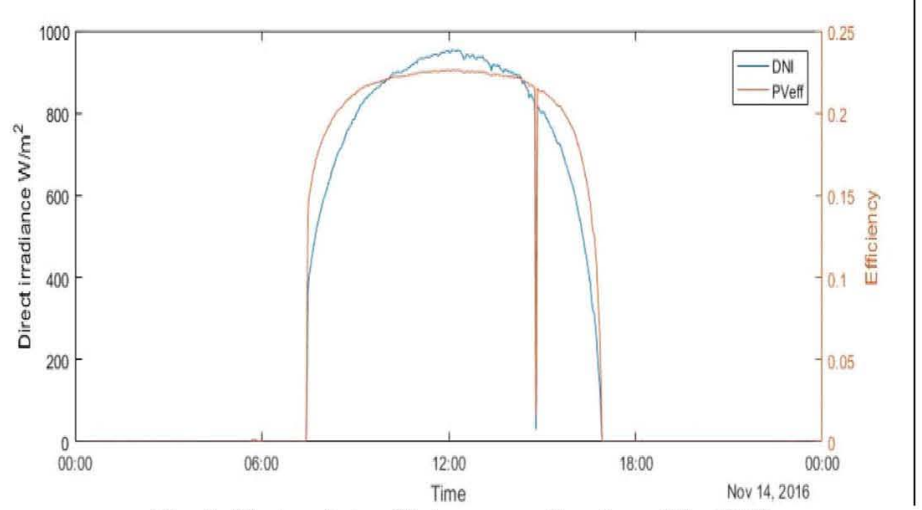

Fig. 5: Photovoltaic efficiency as a function of the DNI

We collect the two photovoltaic efficiencies, which we obtain in the two cases, in the same figure (figure 6). This figure shows that the efficiency with water cooling is better than efficiency without water cooling. The difference can rise a value equal to $4 \%$. So the adding of cooling system makes a big difference. 


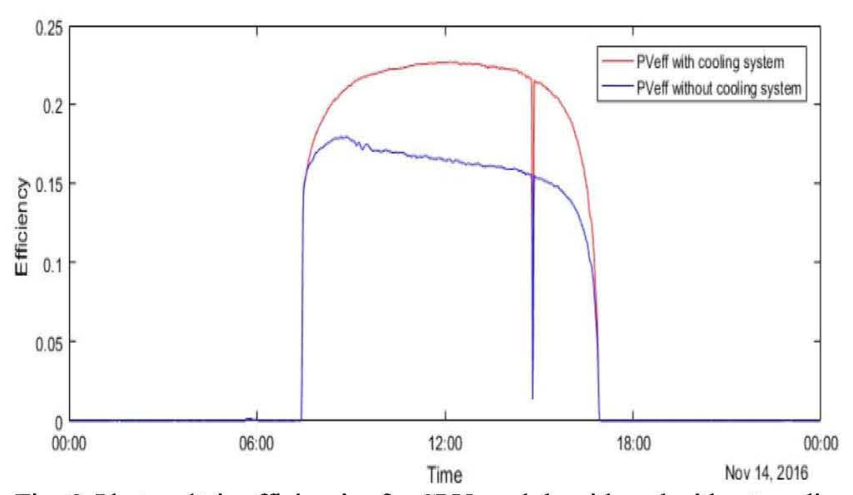

Fig. 6: Photovoltaic efficiencies for CPV module with and without cooling system

\section{CONCLUSION}

The modeling consists to determine the cell temperature and the performance of the concentrating photovoltaic module. The cooling system is a necessary constitution on this modeling. However, the photovoltaic efficiency has been ameliorated and the cell temperature decreased from $65^{\circ} \mathrm{C}$ to $46^{\circ} \mathrm{C}$. This decreasing is a heat which absorbed by the cooling fluid, for that the out fluid temperature increased. We conclude that the cooling system is an important component for the modeling of a concentrating photovoltaic system. So cooling system especially active cooling has been considered as an option to decrease the cell temperature and as an origin of heat for other applications.

\section{REFERENCES}

[1] H. I. Abdelkader, A. Y. Hatata, A. Elansari, M. A. Abo-Elsoud, "Modeling and Simulation of Hybrid Concentrated Photovoltaic/Thermal System", International Journal of Scientific \& Engineering Research, Volume 6, Issue 5, 243, May 2015.

[2] A. Zahedi, "Review of modeling details in relation to low-concentration solar concentrating photovoltaic", in Renewable and Sustainable Energy Reviews 15, pp. 1609-1614, 2011.

[3] P. Pérez-Higueras, E. Munoz, G. Almonacid and P.G. Vidal, "High concentrator photovoltaics efficiencies: Present status and forecast", Renewable and Sustainable Energy Reviews 15, pp. 1810-1815, 2011.

[4] A. Royne, C. J. Dey and D. R. Mills, "Cooling of photovoltaic cells under concentrated illumination: A critical review" in Solar Energy Materials and Solar Cells 86 (4), pp.451-483, April 2005.

[5] A. Luque and V. Andreev, "Concentrator photovoltaics", $1^{\text {st }}$ ed., Vol 130., Springer Series in Optical Sciences, Springer-Verlag Berlin Heidelberg, 2007.

[6] A. Cheknane , B. Benyoucef and A. Chaker, " Performance of concentrator solar cells with passive cooling", in Semiconductor Science and Technology, Vol 21, pp. 144-147, 2006.

[7] IEC committee. 2013. "IEC 62670-1 - CONCENTRATOR PHOTOVOLTAIC (CPV) PERFORMANCE TESTING Part 1: Standard Conditions." IEC 62670. IEC. 